Egypt. J. of Appl. Sci., 36 (5-6) 2021

\title{
ANTIMICROBIAL ACTIVITIES OF SPIRULINA PLATENSIS EXTRACTS AND NANOPARTICLES MATERIAL AGAINST SOME PATHOGENIC BACTERIAL ISOLATES
}

\author{
Omayma A. Awadalla ${ }^{1}$; Nanis G. Allam ${ }^{1}$; Yehia M. Mokhtar ${ }^{2}$; \\ Eslam Baklola $^{2}$; Wagih A. El-Shouny ${ }^{1}$ and M. El-Shetehy ${ }^{1}$ \\ ${ }^{1}$ Microbiology and plant pathology, Botany Department, Faculty of Science, Tanta \\ University \\ ${ }^{2}$ Central Laboratory of Environmental Quality monitoring - National Water Research \\ Center

\section{Eslam_baklola@hotmail.com}

ABSTRACT

The algal species Spirulina platensis have the potential to produce a large number of antimicrobial substances that considered as suitable bio-control agents for plant pathogenic bacteria. The present study aimed to synthesize nano- material of $S$. platensis, use anti-bacteria material of $S$. platensis using solvent extracts and tested them against pathogenic bacteria by Standard well diffusion method for antibacterial activity.

Mullor Hinton Agar (MHA) plates and pure cultures of bacterial pathogens were grown in Nutrient broth at $37^{\circ} \mathrm{C}$ for $18-24$ hours. In the present, the tested positive and negative gram bacteria were isolated from water Omar Bek drainage water-Damietta branch of Nile River

The data of sodium-citrate extraction showed maximum zone of inhibition against all the bacterial isolated while extraction of S. platensis showed minimum inhibition zone against bacterial pathogens in comparison to other solvent extracts. Nano material recorded the highest zone of inhibition against Yersinia pestis $(45 \mathrm{~mm})$ in comparison with Nacitrate against Staphylococcus aureus $(20 \mathrm{~mm})$ as an organic solvent extract. The research concluded and recommended S. platensis should be considered as an economic antibacterial agent than using medical antimicrobials against pathogenic bacteria.

\section{INTRODUCTION}

Spirulina, a blue green alga is now becoming a health food along worldwide. It is an edible, microscopic, multi-cellular, filamentous, alkalophilic, photo auto trophiccyano bacterium that belonging to micro algae of the class Cyanophyta. It consists of a larger cell size for ease of cultivation, for ease of harvest and an easily digestible cell wall. They are considered as rich source of protein, vitamins, and minerals than any 
other single cell protein. Dominating the micro-flora of alkaline saline waters with $\mathrm{pH}$ of up to 11.0 and they can exist in various types of habitats, namely soils; marches, thermal springs uses, fresh water, seawater and brackish, domestic, industrial wastewaters (Jensen and Knutsen, 1993 and Marcello Nicoletti, 2016).

They have been a nature source of medicinal agents for thousands of years. Modern drugs have been isolated from natural sources based on their uses in traditional medicine. Recently many screening of cyanobacteria, antibiotics and other pharmacologically active compounds have received considerable attention (Haidan et al, 2016).

Spirulina as many other cyanobacteria species have the potential to produce a large number of antimicrobial substances that they are considered as bio-control agents of plant pathogenic bacteria and fungi. Algal organisms are rich source of structurally novel and biologically active metabolites that primary or secondary metabolites produced by these organisms may be potential bioactive compounds of pharmaceutical industry (Yuliani et al., 2021).

S. platensis produce a diverse range of bioactive molecules, making them a rich source of different types of medicines, (Kapoor and Mehta 1993; Nasima, et al., 2012). The Spirulina, as a whole, has been known only for its nutritional value but their antimicrobial property of the Cphycocyanin has not been studied in detail in Indian context. Antimicrobial compounds found in cyanobacterial exudates include polyphenols, fatty acids, glycolipids, terpenoids, alkaloids and a variety of yet to be described bacteriocins (Sherif et al., 2021).

Secondary metabolites from cyanobacteria are associated with toxic, hormonal, anti-neoplastic and antimicrobial effects. The antimicrobial substances involved may target various kinds of microorganisms, prokaryotes as well as eukaryotes. The properties of secondary metabolites in nature are not completely understood. Secondary metabolites influence other organisms in the vicinity and are thought to be of phylo-genetic importance. The methods that commonly applied for extraction are based on the agar diffusion principle using pour-plate or spread plate (Seeded plates) techniques. Antimicrobial effects are shown as visible zones of growth inhibition (Inhibition halos) (McGill and Hardy, 1992). The research aimed to synthesize nanomaterial of S. platensis, use anti-bacteria material of $S$. platensis algae using solvent extracts and tested them against pathogenic bacteria by Standard well diffusion method for antibacterial activity. 


\section{MATERIALS AND METHODS}

\subsection{Study area and Sample Collection}

The study area includes about $119 \mathrm{~km}$ (73.94 miles) of the Damietta branch and extended from upstream of the Omar-Bek drain to Faraskour City as shown in Fig.(1). It receives the outlet of three agricultural main drains (Omar Bek, Upper Serw and Drain No.1) where they uploaded with untreated sewage water from many villages. Omar Bek drain is about $130 \mathrm{~km}$ far away from Cairo. It serves about 43,000 feddan (one feddan $=0.42$ ha) of fertile lands and has a discharge rate of about $12,000 \mathrm{~m} / \mathrm{h}$. These wastewaters are collected from industrial, domestic, and agricultural effluents along this drain path from Zefta to Samanoud cities. Omar Bek was initially built as an agricultural drain by the 1980s, and its water quality was in normal ranges till the 1990s. After the 1990s, many environmental issues related to this drain started to be raised (Ezzat and Elkorasey, 2020; Mostafa and Peters, 2016).
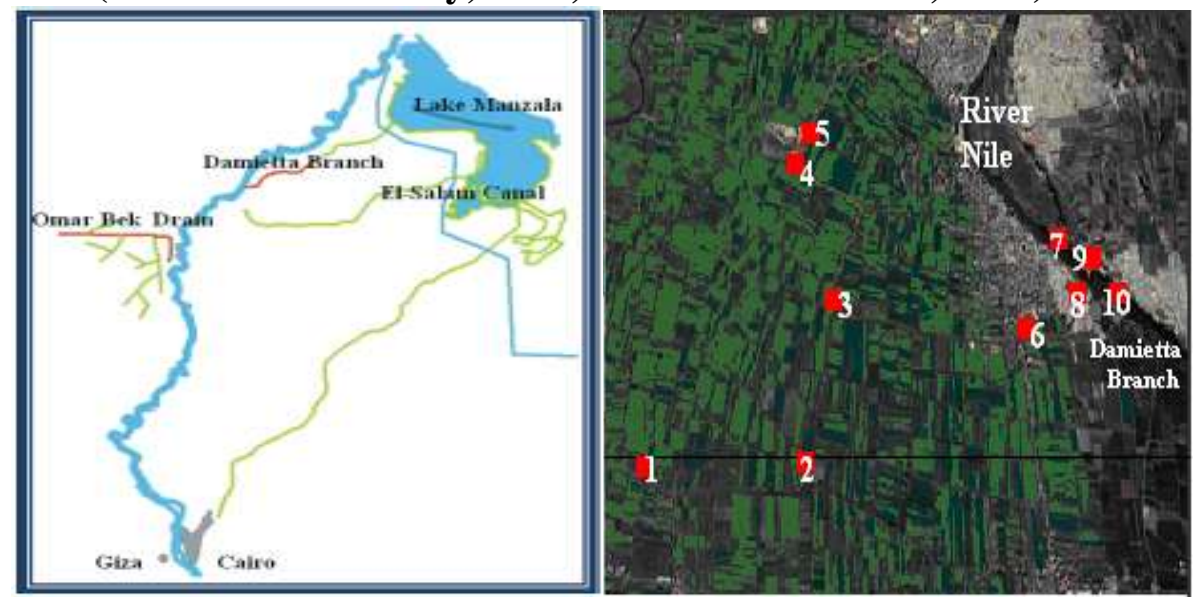

Fig.(1): Map of Study Area Location and Water Samples along Omar

Bek Drain and Damietta Branch-Nile River

In this study, area under investigation ten water samples along Omar Bek drain and from Damietta branch of Nile River, during autumn (on 26 September 2016- from 8.00 a.m. to 10.00 a.m.- air temperature was $\left.31^{\circ} \mathrm{C}\right)$ as shown in Fig.(1). Sampling procedures were carried out according to Standard Methods for Examination of Water and Wastewater (APHA, 2012). All collected samples were stored in an iced cooler box and delivered immediately to the Central Laboratory for Environmental Quality Monitoring, National Water Research Center "CLEQM-NWRC" where it has been analyzed. 


\subsection{Isolation, purification and characterization of bacteria} isolates

\subsubsection{Identification of Bacterial isolates:}

For all wastewater samples, a volume of $100 \mathrm{ml}$ was filtered through $0.47 \mu \mathrm{m}$ pore sized filter using water pump. All selective media used were prepared according to Bergeys Manual (1957) in order to isolate and identify bacteria spp.

\subsubsection{Morphological characteristics of Bacterial isolates:}

Morphological characteristics of colonies color, Gram reaction. Cell Shape, Spore formation, and Motility and Diffusible pigment were investigated. Physiological and biochemical characteristics of pathogenic bacteria isolates were conducted according to tests in Bergeys Manual (1957). Table (1) illustrates the Morphological and biochemical characteristics of identified bacteria isolates from water of Omar bek drain.

\subsubsection{Collection of Pathogenic Bacteria:}

Eleven different bacterial cultures of Gram positive and Gram negative bacteria were isolated from water samples along Omar Bek drain that were:

Gram positive bacteria: Staphylococcus aureus and Enterococcus faecalis.

Gram negative bacteria: Pseudomonas aeruginosa; Serratia liquefaciens; Enterobacter aerogenes; Klebsiella pneumonia; Shigella sonnei; Legionella pneumophila; Yersinia pestis; Moraxella catarrhalis and Hafnia alvei

\subsection{Determination of Antimicrobial Activity of $S$. platensis}

\subsubsection{Preparation of $S$. platensis extract:}

Cells of S. platensis were cultivated in Zarrouk growth media (Fig.2a)

(Zarrouk, 1966) at constant shaking at $30^{\circ} \mathrm{C} \pm 2^{\circ} \mathrm{C}$ and $\mathrm{pH} 10$ in light/dark conditions (16/8 hrs) with shaking of culture manually twice a day. Bacterial cells were harvested after 5-6 days and then washed twice in distilled water. The collected cells were preserved and the supernatant was discarded. The cells of $S$. platensis were stored at -20 until be used.

\subsubsection{Phyto-chemical Extraction:}

About $2 \mathrm{gm}$ of algae fresh weight were added to $10 \mathrm{ml}$ of the desired organic solvent (Na citrate; Ethanol; Hexane; DMSO and acetone) (Fig. 2b, c), mixed well per each organic solvent and then the mixture was exposed to Sonication (Cycle $5 \mathrm{~min}$ on, $5 \mathrm{~min}$ off, $1 \mathrm{~min}$ on, power $100 \%$ on Ice). After Sonication the volume was completed into $100 \mathrm{ml}$ with worm water were add to the sonicated solution. Then, the solution was incubated for 16 hours at $30^{\circ} \mathrm{C}$ with shaking at $150 \mathrm{rpm}$. Water and methanol extraction were performed according to (Tsibakhashvili, et al., 2011). 
Table (1). Morphological and biochemical characteristics of identified bacteria isolates from water of Omar bek drain.

\begin{tabular}{|c|c|c|c|c|c|c|c|c|c|c|c|}
\hline Test & $\begin{array}{c}\text { L. } \\
\text { pneumophila }\end{array}$ & $\begin{array}{c}\text { Y. } \\
\text { pestis }\end{array}$ & $\begin{array}{l}\text { H. } \\
\text { alvei }\end{array}$ & S. liquefaciens & $\begin{array}{c}\text { P. } \\
\text { aeruginosa }\end{array}$ & $\begin{array}{c}\text { S. } \\
\text { aureus }\end{array}$ & $\begin{array}{c}\text { M. } \\
\text { Catarrhalis }\end{array}$ & $\begin{array}{c}\text { E. } \\
\text { faecalis }\end{array}$ & $\begin{array}{c}\text { E. } \\
\text { aerogenes }\end{array}$ & $\begin{array}{c}\text { K. } \\
\text { pneumoniae }\end{array}$ & $\begin{array}{c}\text { S. } \\
\text { sonnei }\end{array}$ \\
\hline $\begin{array}{c}\text { Temp. Limits of } \\
\text { growth }\end{array}$ & $36^{\circ} \mathrm{C}$ & ${ }^{35-37^{\circ} \mathrm{C}}$ & $2.6^{\circ} \mathrm{C}-42^{\circ} \mathrm{C}$ & $30-37^{\circ} \mathrm{C}$ & $\begin{array}{l}37^{\circ} \mathrm{C},-14^{\circ} \mathrm{C} \text { and } \\
+/-41^{1} \mathrm{C}\end{array}$ & $15-45^{\circ} \mathrm{C}$ & $28-37^{\circ} \mathrm{C}$ & $10-45^{\circ} \mathrm{C}$ & $40^{\circ} \mathrm{C}$ & $36^{\circ} \mathrm{C}$ & $35-37^{\circ} \mathrm{C}$ \\
\hline Shape of colony & $\begin{array}{l}\text { Rods and } \\
\text { filaments }\end{array}$ & $\begin{array}{c}\text { Raised } \\
\text { irrigular }\end{array}$ & Straight & Straight rods & straight rods & $\begin{array}{c}\text { Raised, circular } \\
\text { and entire }\end{array}$ & large and kidney & $\begin{array}{c}\text { Small-raised } \\
\text { and entire }\end{array}$ & Rod & Rod & Short rods \\
\hline Texture & Smooth & Smooth & Smooth & Smooth & Smooth & Smooth & Smooth & Smooth & Smooth & Smooth & Smooth \\
\hline Pigmentation & - & - & - & - & $\begin{array}{c}\text { Blue-green } \\
\text { exopigment }\end{array}$ & Golden yellow & - & - & Yellow & - & - \\
\hline Motility & + & - & + & + & + & - & - & - & + & - & - \\
\hline O2 requirements & Aerobic & $\begin{array}{c}\text { facultatively } \\
\text { anaerobic }\end{array}$ & $\begin{array}{c}\text { facultatively } \\
\text { anaerobic }\end{array}$ & Aerobic & $\begin{array}{c}\text { Facultatively } \\
\text { anaerobic }\end{array}$ & $\begin{array}{c}\text { Facultatively } \\
\text { anaerobic }\end{array}$ & Aerobic & $\begin{array}{c}\text { Facultatively } \\
\text { anaerobic }\end{array}$ & $\begin{array}{l}\text { Aerobic/ } \\
\text { anerobic }\end{array}$ & $\begin{array}{c}\text { Facultatively } \\
\text { anaerobic }\end{array}$ & $\begin{array}{c}\text { Facultatively } \\
\text { anaerobic }\end{array}$ \\
\hline Gram reaction & - & - & - & - & - & + & - & + & - & - & - \\
\hline Cell Shape & Rods & Rods & Rod & Rods & Straight rods & $\begin{array}{l}\text { Cocci in clusters } \\
\text { and pairs }\end{array}$ & Kidney & $\begin{array}{l}\text { Cocci in pairs } \\
\text { short chains }\end{array}$ & Rod & Rods & Rod \\
\hline Sporulation & - & - & - & - & - & 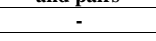 & - & - & - & - & - \\
\hline Capsule & - & + & - & - & - & - & - & - & + & + & - \\
\hline Catalase & + & + & + & + & + & + & + & - & + & + & + \\
\hline Coagulase & & + & + & + & - & + & NA & - & + & + & \\
\hline Oxidase & + & - & & - & + & - & + & - & - & - & - \\
\hline Urease & - & - & - & + & - & + & - & - & - & + & - \\
\hline $\begin{array}{c}\text { Gelatin } \\
\text { liquefaction }\end{array}$ & - & - & - & + & + & + & + & + & - & - & - \\
\hline Starch hydrolysis & + & + & - & + & - & - & + & - & - & - & - \\
\hline $\begin{array}{c}\text { Phyenl amine } \\
\text { deaminase }\end{array}$ & + & - & - & - & - & - & + & - & - & - & - \\
\hline $\mathrm{H}_{2} \mathrm{~S}$ production & - & - & - & - & - & - & + & - & - & - & - \\
\hline $\begin{array}{c}\text { Heamolysis blood } \\
\text { agar }\end{array}$ & $\beta$-Heamolysis & - & $\beta$-Heamolysis & ק-Heamolysis & p-Heamolysis & $\beta$-Heamolysis & - & $\beta$-Heamolysis & $\beta$-Heamolysis & - & - \\
\hline Nitrate reduction & - & + & + & + & - & + & + & - & + & + & + \\
\hline Indol formation & - & - & - & - & - & - & - & - & - & - & - \\
\hline Methyl red & - & + & + & - & - & + & + & - & - & - & + \\
\hline $\begin{array}{c}\text { Tween } 80 \\
\text { hydrolysis }\end{array}$ & + & + & - & - & - & + & - & - & - & - & - \\
\hline Voges-Proskauer & + & - & + & + & - & + & - & + & + & + & - \\
\hline Citrate utilization & + & - & + & + & + & + & 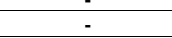 & 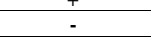 & + & + & - \\
\hline D-glucose & + & + & + & $\mathrm{A} / \mathrm{G}$ & $-1-$ & A/- & - & A/- & $\mathbf{A} / \mathbf{G}$ & $\mathrm{A} / \mathrm{G}$ & + \\
\hline Sucrose & + & & & + & $-1-$ & $\mathrm{A} /-$ & - & $\mathrm{A} /-$ & + & + & - \\
\hline Mannose & + & + & + & + & -1 & $\mathrm{~A} / \mathrm{r}$ & - & $\mathrm{A} /-$ & $\begin{array}{l}+ \\
+ \\
+\end{array}$ & + & + \\
\hline Lactose & + & & & - & -1 & A/- & - & A/- & + & + & - \\
\hline Mannitol & + & + & + & + & A/- & A/- & - & A/- & + & + & - \\
\hline
\end{tabular}

(+), positive result; (-), negative result; (A), (NA), Not Applicable; (A), acidproduction and (G), gas production. 


\subsubsection{Antimicrobial activity of the obtained algae nano silver}

In vitro antimicrobial activities had been examined for 11 pathogenic bacteria using the agar disk diffusion method according to (Attaie, et al., 1987). Inhibition zones of growth around the disks were measured after 24 hours of incubation at $37^{\circ} \mathrm{C}$. The nano-particle activity was compared with some other of generic antibiotics.

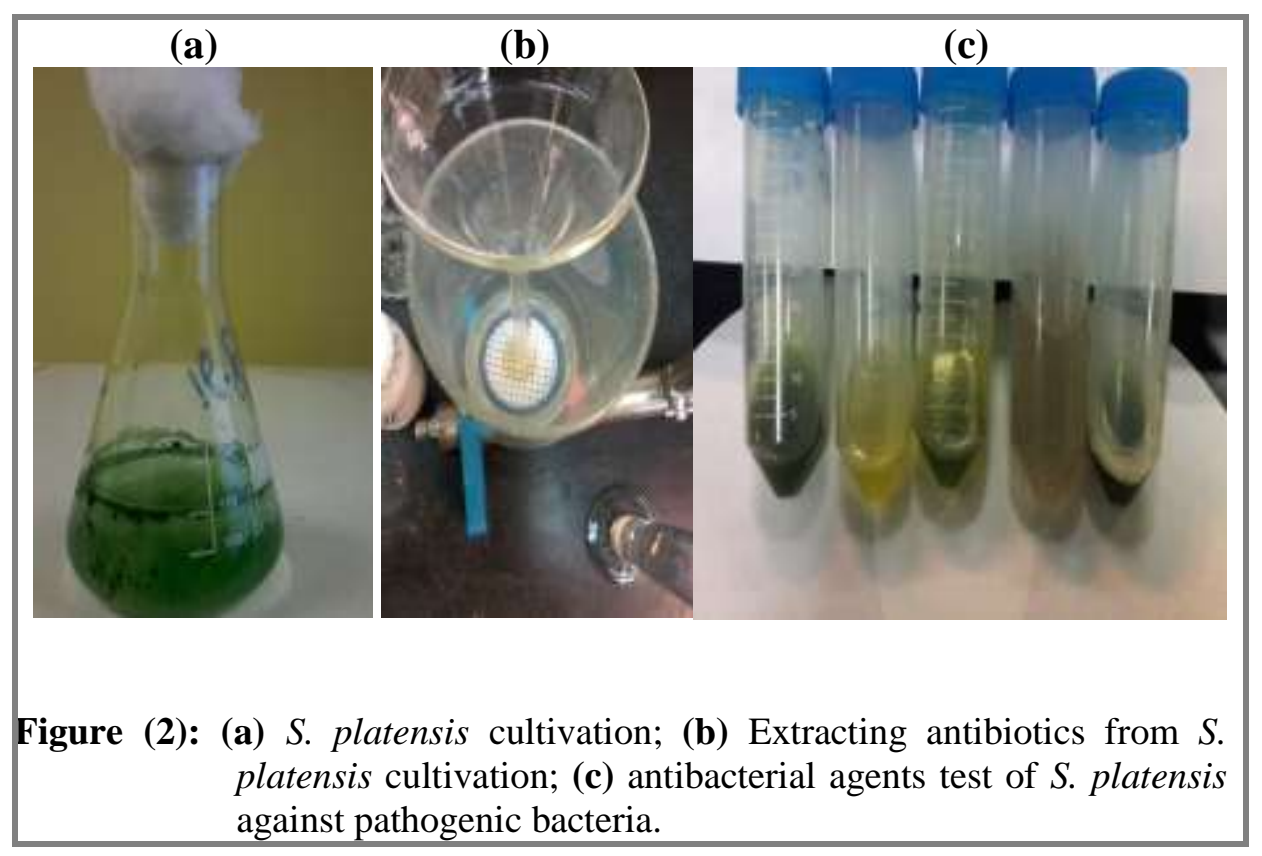

\subsubsection{Determination of Antibacterial Activity by Well Diffusion Method}

The wet biomass of $S$. platensis (1g) was re-suspended in $500 \mathrm{ml}$ Erlenmeyer flask with $100 \mathrm{ml}$ of $10^{-3} \mathrm{M}$ aqueous silver nitrate (preparing $1 \mathrm{mM}$ of Silver nitrate $\left(\mathrm{AgNO}_{3}\right)$ solution: dissolving $0.169 \mathrm{~g}$ of $\mathrm{AgNO}_{3}$ (Sigma, 99\%, 169.87g/mol) in 1 liter of de-ionized water.) by using deionized water $(\mathrm{pH} 7)$ incubated at room temperature for different time intervals (1-5 days). (Kalabegishvili et al., 2012; Devina et al., 2010).

The AgNPs synthesized from $S$. platensis was tested for its antibacterial activity against pathogenic bacteria by standard well diffusion method in Mullor Hinton Agar (MHA) plates. Pure cultures of bacterial pathogens were grown in Nutrient broth at $37^{\circ} \mathrm{C}$ for $18-24$ hours. 
Wells were done on Moller-Hinton agar plates by using gel puncture and plates were inoculated by scavenging bacterial pathogens in order to create a confluent turf of the bacterial growth. After incubation at $37^{\circ} \mathrm{C}$ for 24 hours, diameter of zone of inhibition in millimeter around each well was measured (Thomas et al., 2012).

In this study, we used $S$. platensis algae as natural antibacterial through phytochemical extraction with other organic solvents, against pathogenic bacteria. We used $S$. platensis as natural nano material through mixing algae with $\mathrm{AgNO}_{3}$ solution, against pathogenic bacteria

\section{RESULTS AND DISCUSSION \\ 3.1 Antibacterial Activity of Organic Antibacterial Solvents of $S$. platensis}

The antibacterial activity of $S$. platensis was determined against bacteria and the findings were furnished in the Table (2), Figures ( 3 and 4). The zone of inhibition of $S$. platensis extracts against bacteria was ranged between $5 \mathrm{~mm}$ to $45 \mathrm{~mm}$ at $200 \mu \mathrm{l}$. The Na-citrate extract of $S$. platensis showed the highest mean zone of inhibition $(20 \mathrm{~mm})$ against the Gram positive cocci Staphylococcus aureus, followed by Enterococcus faecalis $(15 \mathrm{~mm})$, in comparison to other organic solvents. The minimum zone of inhibition obtained from the acetone extract of S. platensis against bacterial pathogens was comparatively very less when compared to the other solvent extracts (Saranraj, 2015).

For Gram negative bacteria, the maximum zone of inhibition was recorded also in Na-citrate extract of S. platensis against Yersinia pestis $(17 \mathrm{~mm})$ followed by Serratia liquefaciens $(16 \mathrm{~mm})$, Klebsiella pneumoniae $(15 \mathrm{~mm})$, Legionella pneumophila $(13 \mathrm{~mm})$, Moraxella catarrhalis $(11 \mathrm{~mm})$, both Pseudomonas aeruginosa and Shigella sonnei were recorded (10mm), Hafnia alvei $(7 \mathrm{~mm})$ and Enterobacter aerogenes $(5 \mathrm{~mm})$. No zone of inhibition was seen in DMSO and ethanol with both gram positive and negative bacteria, in agreement with data of Saranraj, et al., (2015). Kaushik and Chauhan (2008) reported that extracts of $S$. platensis inhibited the growth diameter of Staphylococcus aureus, Escherichia coli, Pseudomonas aeruginosa, Salmonella typhi and Klebsiella pneumoniae. They used hexane, ethyl acetate, dichloromethane and methanol to obtain the phenolic extracts and the methanolic extracts had the best results. The methane extract of Staphylococcus aureus and Escherichia coli minimum inhibitory concentrations (MIC) were $128 \mu \mathrm{g} / \mathrm{ml}$ and $256 \mu \mathrm{g} / \mathrm{ml}$ respectively. 


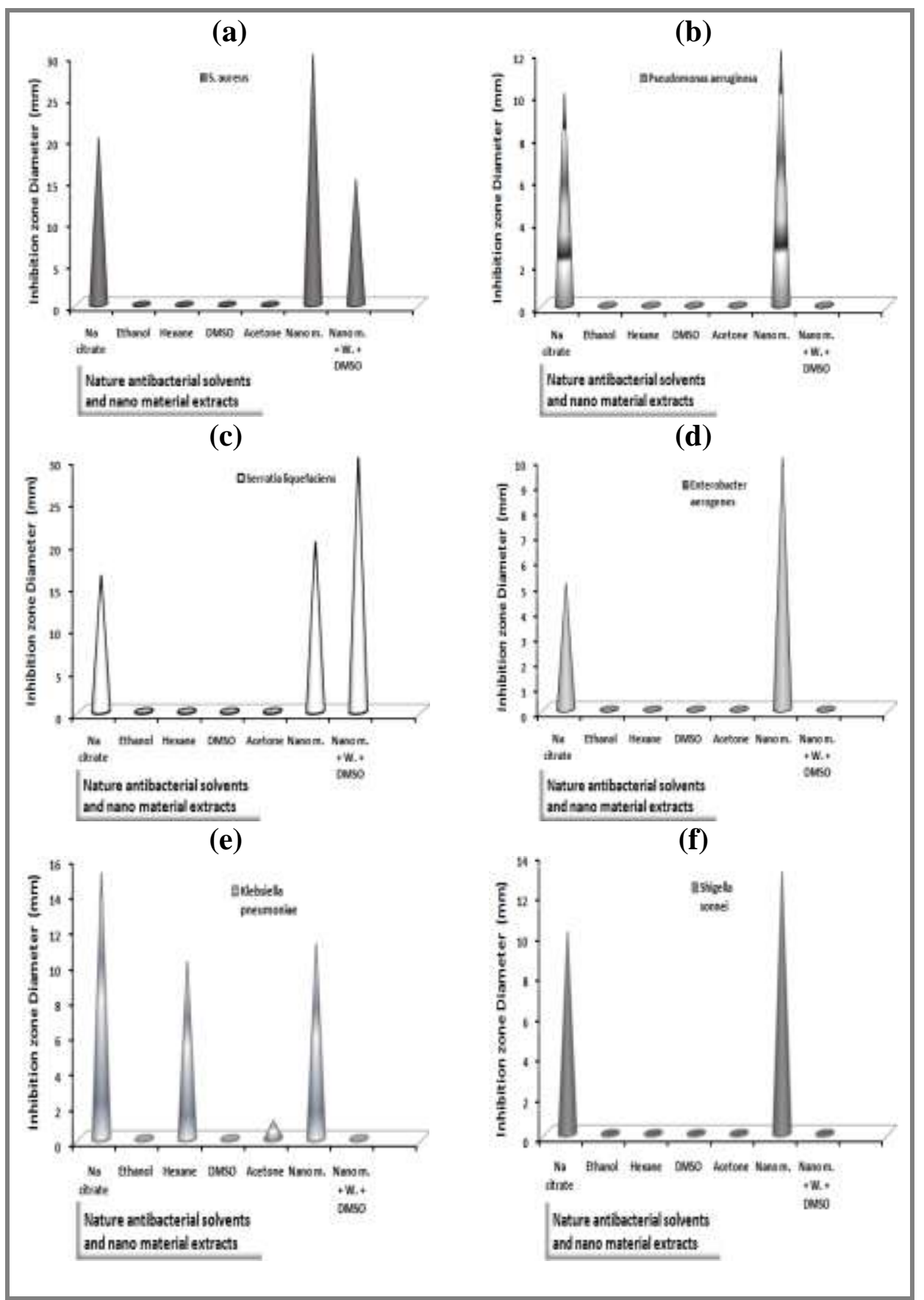

Figure (3) Resistance of (a) Staphylococcus aureus; (b) Pseudomonas aeruginosa; (c) Serratia liquefaciens; (d) Enterobacter aerogenes ; (e) Klebsiella 


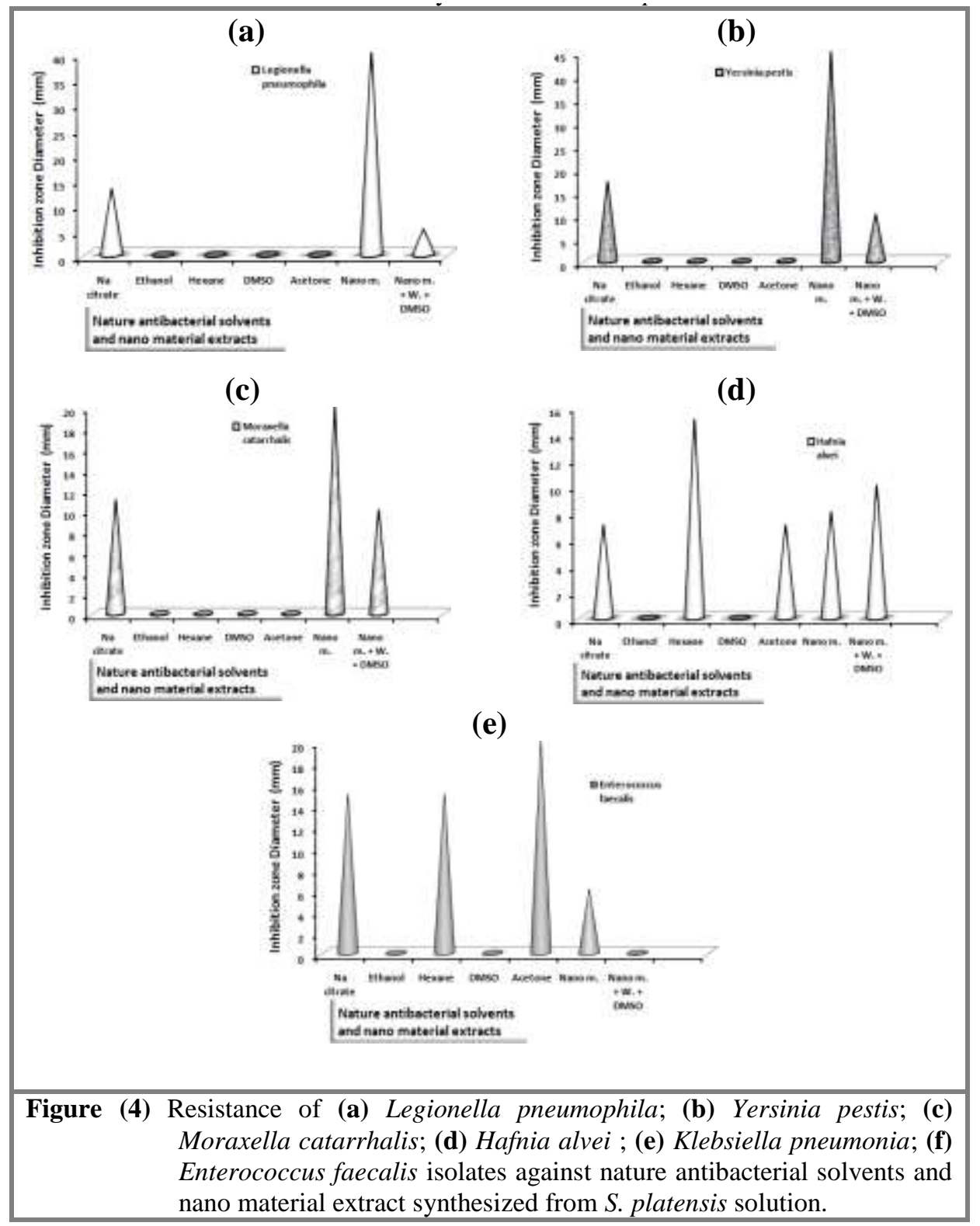

Parisi et al., (2009) also found high antimicrobial activity of phenolic compounds extracted with methanol from $S$. platensis against Gram positive Staphylococcus aureus. Vinay Kumar et al., (2011) examined the algal extracts in vitro for their antibacterial effects against (Staphylococcus aureus and Salmonella typhimurium) using Agar well 
diffusion method and Paper disc diffusion method with concentration from 250ppm to $7000 \mathrm{ppm}$ and it noticed that all of these bacteria showed inhibition in the growth of these extracts.

Table (2): Antibacterial Activity of Organic Solvents and Nano Mmaterial Synthesized by S. platensis

\begin{tabular}{|c|c|c|c|c|c|c|c|}
\hline Isolates & \multicolumn{5}{|c|}{ Organic Solvents + Algae } & \multicolumn{2}{|c|}{ Algae as Nano Material } \\
\hline & $\underline{\text { Na citrate }}$ & Ethanol & $\underline{\text { Hexane }}$ & $\underline{\text { DMSO }}$ & Acetone & $\frac{\text { Nano Material }}{\underline{\text { only }}}$ & $\begin{array}{l}\text { Nano Material } \\
+ \text { Water } \\
\text { + DMSO }\end{array}$ \\
\hline Staphylococcus aureus & 20 & -ve & -ve & -ve & -ve & 30 & $\overline{15}$ \\
\hline Pseudomonas aeruginosa & 10 & -ve & -ve & -ve & -ve & 12 & -ve \\
\hline Serratia liquefaciens & 16 & -ve & -ve & -ve & -ve & 20 & 30 \\
\hline Enterobacter aerogenes & 5 & -ve & -ve & -ve & -ve & 10 & -ve \\
\hline Klebsiella pneumoniae & 15 & -ve & 10 & -ve & 10 & 11 & -ve \\
\hline Shigella sonnei & 10 & -ve & $-\mathrm{ve}$ & -ve & -ve & 13 & -ve \\
\hline Legionella pneumophila & 13 & -ve & -ve & -ve & -ve & 40 & 5 \\
\hline Yersinia pestis & 17 & -ve & -ve & -ve & -ve & 45 & 10 \\
\hline Moraxella catarrhalis & 11 & -ve & -ve & $-\mathrm{eve}$ & $-\mathrm{ve}$ & 20 & 10 \\
\hline Hafnia alvei & 7 & -ve & 15 & $-\mathrm{ve}$ & 7 & 8 & 10 \\
\hline Enterococcus faecalis & 15 & -ve & 15 & -ve & 20 & 6 & -ve \\
\hline
\end{tabular}

(-ve), negative result

\section{Antibacterial activity of AgNPs synthesized by $S$. platensis}

The antibacterial activity of biosynthesized silver nano-particle was performed against both gram positive bacteria as mentioned before by well diffusion method. The zone of inhibition of $S$. platensis extracts against bacteria was ranged between $5 \mathrm{~mm}$ to $45 \mathrm{~mm}$ at $200 \mu \mathrm{l} /$ well. The nano material extract of $S$. platensis showed the highest mean zone of inhibition $(30 \mathrm{~mm})$ against the gram positive cocci Staphylococcus aureus, followed by Enterococcus faecalis $(6 \mathrm{~mm})$, in comparison to nano material + water + DMSO.

For Gram negative bacteria, the maximum zone of inhibition was recorded also in nano material extracts of $S$. platensis against Yersinia pestis $(45 \mathrm{~mm})$ followed by Legionella pneumophila $(40 \mathrm{~mm})$, both Moraxella catarrhalis and Serratia liquefaciens (20mm), Shigella sonnei $(13 \mathrm{~mm})$, Pseudomonas aeruginosa $(12 \mathrm{~mm})$, Klebsiella pneumoniae $(11 \mathrm{~mm})$, Enterobacter aerogenes $(10 \mathrm{~mm})$, and Hafnia alvei $(8 \mathrm{~mm})$.

By increasing the volume of AgNPs synthesized S. platensis to 100 $\mu \mathrm{L} /$ well the zone of inhibition increases for both gram positive and negative bacteria. However, a Silver Nano particle has showed antibacterial activities more than Na-citrate solvent. This study in agreement with Theivasanthi and Alagar (2011) that reported Silver nano particles material have showed high antibacterial activities in comparison with other extracts.

The efficiency of the biosynthesized nano-material against the tested bacteria could be attributed to the adherence of small sized nano- 
material to the bacterial cell membrane surface and thus disturbing its permeability and respiration functions (Jagtap and Bapat, 2013).

The utilization of $S$. platensis as antibacterial reagents or as nano material solution has various advantages like easy cultivation and availability. This biological method approach toward the synthesis of nano-material has numerous benefits, that is, non-toxicity, cost effectiveness, rapid reduction, and economic viability. Future prospects of this research would be large scale production of nano material using $S$. platensis and ascertaining its effectiveness against a broad spectrum of microbial populations. In addition to other investigations that will coverage of the $S$. Platensis effectiveness to synthesis silver nanoparticles.

\section{CONCLUSION}

Synthesis of $S$. platensis algae as nano-material using organic solvents was carried out and tested for its antibacterial activity against pathogenic bacteria. It was clear that $\mathrm{Na}$-citrate extract showed maximum zone of inhibition against all the bacterial while hexane extract of $S$. platensis showed minimum inhibition zone against bacterial pathogens. Nano material recorded the highest zone of inhibition against Yersinia pestis $(45 \mathrm{~mm})$ in comparison with organic solvent extract (Na-citrate) against Staphylococcus aureus $(20 \mathrm{~mm})$. S. platensis should be considered as an economic antibacterial agent than using medical antimicrobials against pathogenic bacteria. Other Future prospects of this research would be large scale production of AgNPs using S. platensis and at different concentrations in order to explore more benefits of $S$. platensis as bio-antibacterial for pathogenic bacteria.

\section{REFERENCES}

APHA, [American Public Health Association] (2012). Standard Methods for the Examination of Water and Wastewater $20^{\text {th }}$ ed. APHA, Inc. Washington, DC.

Attaie, R.J. ; K.M. Whalen, and M.A. Arner (1987). Inhibition of growth of S. aureus during production of acidophilus yogurt. J. Food Protec, 50: 224- 228.

Breed, R.S. ; E.G.D. Murray, and N.R. Smith (1957). Bergey's manual of determinative bacteriology. The Williams \& wilkins company. Seventh edition.

Devina, M.D. ; S. Prakash and B.V. Bhimba (2010). Antibacterial screening of silver nano-particles synthesized by marine micro algae. Asian Pacific Journal of Tropical Medicine, 3(10):797-799. 
Ezzat, S.M. and R.M. Elkorashy (2020). Wastewater as a Nonconventional Resource: Impact of Trace Metals and Bacteria on Soil, Plants and human Health. Human and Ecological Rick assessment: An International Journal, 26(8): 2245-2265

Haidan Yuan ; Qianqian Ma ; Li Ye and Guangchun Piao (2016). The Traditional Medicine and Modern Medicine from. Natural Products. Molecules, 21, 559; doi:10.3390/molecules21050559

Jagtap, U.B. and V. Bapat (2013). A Green synthesis of silver nanoparticles using Artocarpus heterophyllus Lam. seed extract and its antibacterial activity. Ind. Crops Prod., 46:132-137.

Jensen, S. and G. Knutsen (1993). Influence of light and temperature on photoinibition of photosynthesis in Spirulina platensis. Journal of Applied Phycology, 5: 495-504.

Kalabegishvili, T. ; E. Kirkesali ; M.V. Frontasyeva ; S.S. Pavlov ; I. Zinicovscaia and A. Faanhof (2012). Synthesis of gold nanoparticles by blue-green algae Spirulina platensis. Proceedingsof the International Conference Nanomaterials: Applications and Properties, 1(2): 02NNBM09 (3pp). Sumy State University Publishing.

Kapoor, R. and U. Mehta (1993). "Effect of supplementation of blue green alga (Spirulina) on outcome of pregnancy in rats." Plant Foods and Human Nutrition, 43(1): 29-35.

Kaushik, P. and A. Chauhan (2008). In vitro antibacterial activity of laboratory grown culture of Spirulina platensis. Indian Journal of Medical Microbiology, 48: 348-52.

Marcello Nicoletti, (2016). Microalgae Nutraceuticals. FoodsJournal, 5(3), 54; https://doi.org/10.3390/foods5030054

McGill, A.S. and R. Hardy (1992). Review of the methods used in the determination of antibiotics and their metabolites in farmed fish. In: Michel C, Alderman DJ, eds. Chemotherapy in Aquaculture: from Theory to Reality. Paris, France: Office International Des Epizooties, pp: 343-380.

Mostafa, M.K. and R.W. Peters (2016). Effect of Changing the Effluent Path of Omar -Bek Drain on the Damietta Branch Water Quality. Journal of Water Resource and Protection. 8(1).

Nasima Akhtara ; Monzur Morshed Ahmeda ; Nishat Sarkerb ; Khandaker Rayhan Mahbuba and Abdul Matin Sarkera (2012). Growth response of Spirulina platensis in papaya skin extract and antimicrobial activities of Spirulina extracts in different 
culture media Bangladesh. Journal of Science and Industrial Research, 47(2): 147-152.

Parisi, A.S. ; S. Younes ; C.O. Reinehr and L.M. Colla (2009). Assessment of the antibacterial activity of microalgaeSpirulina platensis. Revista de Ciências Farmacêuticas Básicae Aplicada, Araraquara, 30(3): 97-301.

Saranraj, P. ; S. Sivasakthi ; G. Srinivasan and G. Usharani (2015). Antimicrobial Activity of Spirulina platensis SolventExtracts Against Pathogenic Bacteria and Fungi. Advances in Biological Research, 9 (5): 292-298.

Sherif R. Abdel-All ; Zeinab T. Abdel Shakour ; Dalia MN Abou Hussein and Azza R. Abdel-Monem (2021). Phytochemical and Biological Evaluation of a Newly Designed Nutraceutical Self-Nanoemulsifying Self-Nanosuspension for Protection and Treatment of Cisplatin Induced Testicular Toxicity in Male. Molecules Journal, Vol. 26(2):408, DOI:10.3390/molecules26020408

Theivasanthi, T. and M. Alagar (2011). Antibacterial studies of silver nano-particles. General Physics, Cornell University Library.

Thomas, R. ; A. Viswan ; J. Mathew and E.K. Radhakrishnan (2012). Evaluation of antibacterial activity of silver nano-particles synthesized by a novel strain of marine Pseudomonas sp. Nano Biomedicine and Engineering, 9:139-143.

Tsibakhashvili, N.Y. ; E.I. Kirkesali ; D.T. Pataraya ; M.A. Gurielidze ; T.L. Kalabegishvili ; D.N. Gvarjaladze ; G.I. Tsertsvadze ; M.V. Frontasyeva ; I.I. Zinicovscaia ; M.S. Wakstein ; S.N. Khakhanov ; N.V. Shvindina and V.Y. Shklover (2011). Microbial Synthesis of Silver Nano particles by Streptomyces glaucus and Spirulina platensis. Advanced Science Letters, 4: 1-10

Vinay Kumar ; A.K. Bhatnagar and J.N. Srivastava (2011). Antibacterial activity of crude extracts of Spirulina platensis and its structural elucidation of bioactive compound. Journal of Medicinal Plants Research, 5(32): 7043-7048.

Yuliani, Y. ; Putut Har Riyadi ; Eko Dewi and Irwandi Jaswir (2021). Ocimum basilicum (kemangi) intervention on powder and microencapsulated Spirulina platensis and its bioactive molecules. F1000Research 2021, 10:485 Last updated: 18 JUN 2021, DOI:10.12688/f1000research.52394.1

Zarrouk, C. (1966). Contribution à l'étuded'unecyanophycée. Influence de divers' facteurs physiques et chimiques sur la croissance et la photosynthèse de Spirulina maxima. (Setch et Gardner) Geitler. Ph.D. Thesis, Université de Paris, Paris, France. 
الأنثطة الميكرويية للسبيرولينا بلاتنيس كمضاد حيوي وكمادة نانونية لبعض

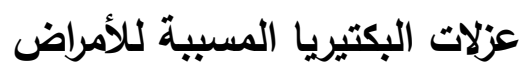

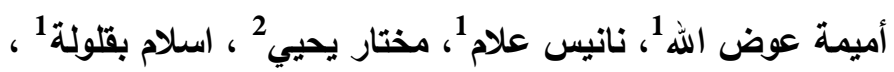

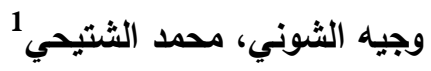

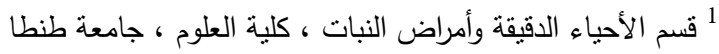

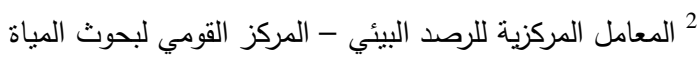

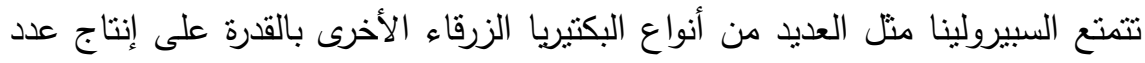

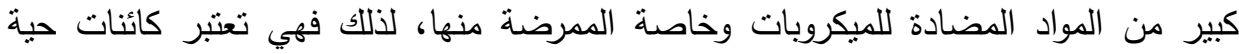

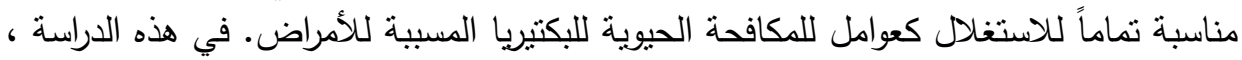

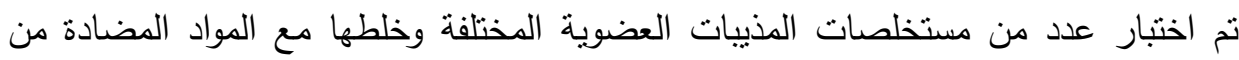

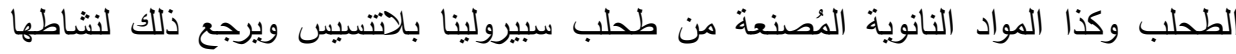

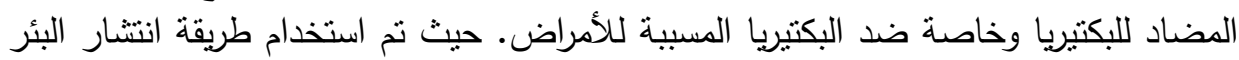

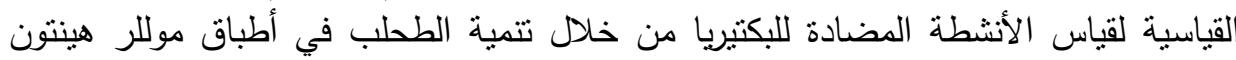

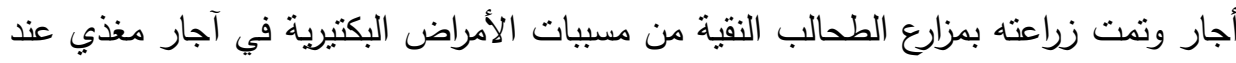

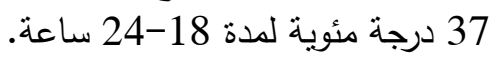

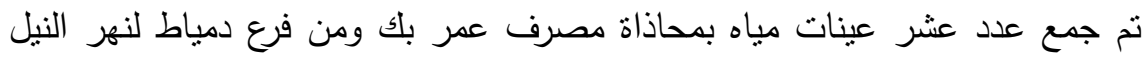

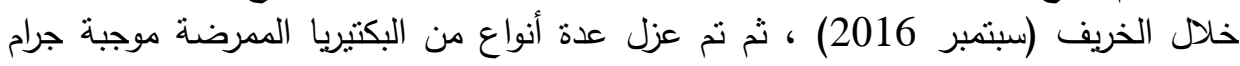

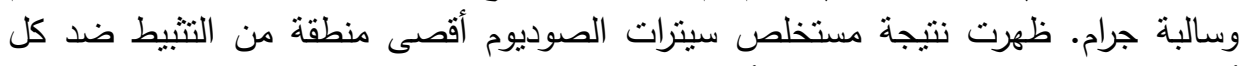

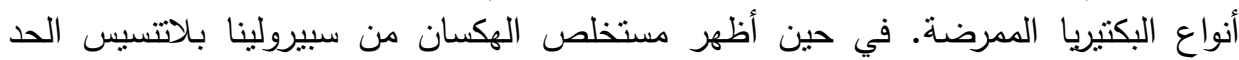

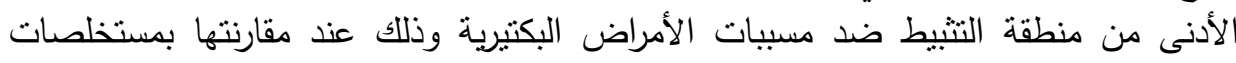

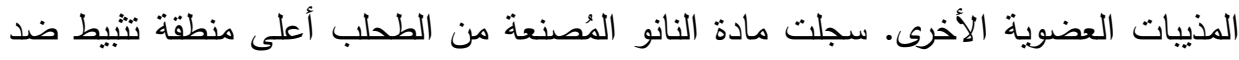

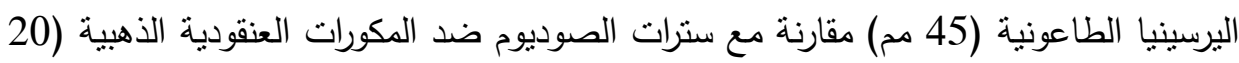

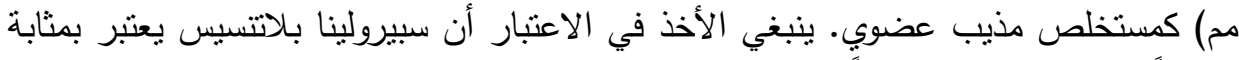
مضاداً اقتصاديًا للبكتيريا بدلاً من استخدام مضادات الميكروبات الطبية ضد البكتيريا المسببة لانية 